\title{
Prediction of surface roughness in the ball-end milling process using response surface methodology, genetic algorithms, and grey wolf optimizer algorithm
}

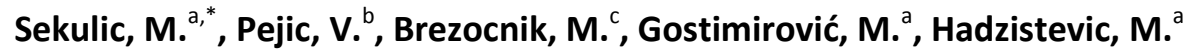 \\ aniversity of Novi Sad, Faculty of Technical Sciences, Department of Production Engineering, Novi Sad, Serbia \\ ${ }^{b}$ College of Business and Technical Education, Doboj, Bosnia and Herzegovina \\ ${ }^{c}$ University of Maribor, Faculty of Mechanical Engineering, Production Engineering Institute, Maribor, Slovenia
}

\section{A B S T R A C T}

In this research study proposed are a response surface methodology (RSM), genetic algorithm (GA) and a grey wolf optimizer (GWO) algorithm for prediction of surface roughness in ball-end milling of hardened steel. The RSM is a conventional predicting approach, GA is an evolutionary algorithm and GWO is a new swarm intelligence-based algorithm. Spindle speed, feed per tooth, axial depth and radial depth of cut were selected as input parameters. Experiments were performed on a CNC milling center and experimental data were collected based on a four-factor-five-level central composite design (CCD). RSM was applied for establishing the basic relationship between input parameters and surface roughness. After that analysis of variance (ANOVA) was conducted for the evaluation of the proposed mathematical model. A predefined reduced quadratic model was used as a reference model for a build-up of predictive models using GA and GWO algorithm. Predicted values of RSM, GA and GWO models are compared with experimental results. In the comparison of model performance for all the three models it was found that GWO model is the best solution. The model accuracy was found to be at $91.80 \%$ and $89.58 \%$ for training and testing data, respectively, which showed the effectiveness of the GWO algorithm for modeling machining processes.
\end{abstract}

\section{ARTICLE INFO}

Keywords:

Ball-end milling;

Surface roughness;

Response surface methodology

(RSM);

Genetic algorithm (GA);

Grey wolf optimizer algorithm

(GWO)

*Corresponding author:

milenkos@uns.ac.rs

(Sekulic, M.)

Article history:

Received 21 November 2017

Revised 28 January 2018

Accepted 15 February 2018

\section{References}

[1] Van Luttervelt, C.A., Childs, T.H.C., Jawahir, I.S., Klocke, F., Venuvinod, P.K., Altintas, Y., Armarego, E., Dornfeld, D., Grabec, I., Leopold, J., Lindstrom, B., Lucca, D.,Obikawa, T., Shirakashi, Sato, H. (1998). Present situation and future trends in modelling of machining operations progress report of the CIRP working group 'Modelling of machining operations', CIRP Annals, Vol. 47., No. 2, 587-626, doi: 10.1016/S0007-8506(07)63244-2.

[2] Arrazola, P.J., Özel, T., Umbrello, D., Davies, M., Jawahir, I.S. (2013). Recent advances in modelling of metal machining processes, CIRP Annals, Vol. 62., No. 2, 695-718, doi: 10.1016/j.cirp.2013.05.006.

[3] Finnie, I. (1956). Review of the metal cutting analysis of the past hundred years, Mechanical Engineering, Vol. 78, No. 8, 715-721.

[4] Venkata Rao, R. (2011). Advanced modelling and optimization of manufacturing processes, Springer-Verlag, London ,United Kingdom, doi: 10.1007/978-0-85729-015-1.

[5] Siddique, N., Adeli, H. (2015). Nature inspired computing: An overview and some future directions, Cognitive Computation, Vol. 7, No. 6, 706-714, doi: 10.1007/s12559-015-9370-8.

[6] Kar, A.K. (2016). Bio inspired computing - A review of algorithms and scope of applications, Expert Systems with Applications, Vol. 59, 20-32, doi: 10.1016/j.eswa.2016.04.018. 
[7] Simunovic, G., Simunovic, K., Saric, T. (2013). Modelling and simulation of surface roughness in face milling. International Journal of Simulation Modelling, Vol. 12, No. 3, 141-153, doi: 10.2507/IJSIMM12(3)1.219.

[8] Lou, S.-J. (1997). Development of four in-process surface recognition systems to predict surface roughness in end milling, Ph.D. Thesis, Iowa State University, Iowa, USA.

[9] Lou, M.S., Chen, J.C., Li, C.M. (1998). Surface roughness prediction technique for CNC end-milling, Journal of Industrial Technology, Vol. 15, No. 1, 2-6.

[10] Chen, J.C., Lou, M.S. (2000). Fuzzy-nets based approach to using an accelerometer for in-process surface roughness prediction system in milling operations, International Journal of Computer Integrated Manufacturing, Vol. 13, No. 4, 358-368, doi: 10.1080/095119200407714.

[11] Ali, Y.M., Zhang, L.C. (1999). Surface roughness prediction of ground components using a fuzzy logic approach, Journal of Material Processing Technology, Vol. 89-90, 561-568, doi: 10.1016/S0924-0136(99)00022-9.

[12] Chen, J. (2000). Neural networks and neural-fuzzy approaches in an in-process surface roughness recognition system for end milling, In: Kusiak, A., Wang, J. (eds.), Computational intelligence in manufacturing handbook, CRC Press, Boca Raton, USA, doi: 10.1201/9781420041934.ch16.

[13] Suresh, P.V.S., Venkateswara Rao, P., Deshmukh, S.G. (2002) A genetic algorithmic approach for optimization of surface roughness prediction model, International Journal of Machine Tools and Manufacture, Vol. 42, No. 6, 675680, doi: 10.1016/S0890-6955(02)00005-6.

[14] Tamiloli, N., Venkatesan, J., Vijaya Ramnath, B. (2016). A grey-fuzzy modeling for evaluating surface roughness and material removal rate of coated end milling insert, Measurement, Vol. 84, 68-82, doi: 10.1016/ j.measurement. 2016.02.008.

[15] Karkalos, N.E., Galanis, N.I., Markopoulos, A.P. (2016). Surface roughness prediction for the milling of Ti-6Al-4V ELI alloy with the use of statistical and soft computing techniques, Measurement, Vol. 90, 25-35, doi: 10.1016/ j.measurement.2016.04.039.

[16] Brezocnik, M., Kovacic, M., Ficko, M. (2004). Prediction of surface roughness with genetic programming, Journal of Materials Processing Technology Vol. 157-158, 28-36, doi: 10.1016/i.jmatprotec.2004.09.004.

[17] Dhokia, V.G., Kumar, S., Vichare, P., Newman, S.T. (2008). An intelligent approach for the prediction of surface roughness in ball-end machining of polypropylene, Robotics and Computer-Integrated Manufacturing, Vol. 24, No. 6, 835-842, doi: 10.1016/j.rcim.2008.03.019.

[18] Vakondios, D., Kyratsis, P., Yaldiz, S., Antoniadis, A. (2012). Influence of milling strategy on the surface roughness in ball end milling of the aluminum alloy Al7075-T6, Measurement, Vol. 45, No. 6, 1480-1488, doi: 10.1016/j. measurement.2012.03.001.

[19] Hossain, S.J., Ahmad, N. (2012). Surface roughness prediction modeling for AISI 4340 after ball end mill operation using artificial intelligence, International Journal of Scientific \& Engineering Research, Vol. 3, No. 5, 1-10, doi: 10.3968/i.mse.1913035X20120602.2933.

[20] Zuperl, U., Cus, F. (2015). Simulation and visual control of chip size for constant surface roughness, International Journal of Simulation Modelling, Vol. 14, No. 3, 392-403, doi: 10.2507/IJSIMM14(3)2.282.

[21] Quintana, G., Garcia-Romeu, M.L., Ciurana, J. (2011). Surface roughness monitoring application based on artificial neural networks for ball-end milling operations, Journal of Intelligent Manufacturing, Vol. 22, No. 4, 607-617, doi: 10.1007/s10845-009-0323-5.

[22] Pejic, V. (2016). Modeling and optimization in the ball end milling process (original Serbian title: Modelovanje $i$ optimizacija procesa glodanja vretenastim glodalima), Ph.D. Thesis, University of Novi Sad, Serbia.

[23] Myers, R.H., Montgomery, D.C., Anderson-Cook, C.M. (2009). Response surface methodology: Process and product optimisation using designed experiments, 3rd edition, John Wiley \& Sons, New Jersey, USA.

[24] Sung, A.N., Loh, W.P., Ratnam, M.M. (2016). Simulation approach for surface roughness interval prediction in finish turning, International Journal of Simulation Modelling, Vol. 15, No. 1, 42-55, doi: 10.2507/IJSIMM15(1) $\underline{4.320 .}$.

[25] Boyacı, A.İ., Hatipoğlu, T., Balcı, E. (2017). Drilling process optimization by using fuzzy-based multi-response surface methodology, Advances in Production Engineering \& Management, Vol. 12, No. 2, 163-172, doi: 10.14743/ apem2017.2.248.

[26] Zain, A.M., Haron, H., Sharif, S. (2010). Application of GA to optimize cutting conditions for minimizing surface roughness in end milling machining process, Expert Systems with Applications, Vol. 37, No. 6, 4650-4659, doi: 10.1016/j.eswa.2009.12.043.

[27] Mirjalili, S., Mirjalili, S.M., Lewis, A. (2014). Grey wolf optimizer, Advances in Engineering Software, Vol. 69, 4661, doi: $10.1016 /$ i.advengsoft.2013.12.007.

[28] Rezaei, H., Bozorg-Haddad, O., Chu, X. (2018). Grey wolf optimization (GWO) algorithm, In: Bozorg-Haddad, 0. (ed.), Advanced optimization by nature-inspired algorithms, Springer Nature, Singapore, 81-92, doi: 10.1007/ 978-981-10-5221-7.

[29] Tamang, S.K., Chandrasekaran, M. (2015). Modeling and optimization of parameters for minimizing surface roughness and tool wear in turning $\mathrm{Al} / \mathrm{SiCp} \mathrm{MMC}$, using conventional and soft computing techniques, Advances in Production Engineering \& Management, Vol. 10, No. 2, 59-72, doi: 10.14743/apem2015.2.192. 